\title{
Stakeholder Management of Jakarta's Light Rail Transit Using Stakeholder Analysis
}

\author{
Khrisna Yudi ${ }^{1,2}$, Ayomi Dita Rarasati ${ }^{1,2 *}$, Achmad Jaka Santos Adiwijaya ${ }^{3}$ \\ ${ }^{1}$ Civil Engineering Department, Faculty of Engineering, \\ Universitas Indonesia, Kampus UI Depok, Jawa Barat, Indonesia 16424 \\ ${ }^{2}$ Center for Sustainable Infrastructure Development, Faculty of Engineering, \\ Universitas Indonesia, Kampus UI Depok, Jawa Barat, Indonesia 16424 \\ ${ }^{3}$ Garuda Indonesia, Gedung Garuda Indonesia Jl. Kebon Sirih No. 44 Jakarta Pusat, Indonesia
}

\begin{abstract}
Stakeholders involvement in infrastructure development c.q. Light Rail Transit (LRT) has a significant role since they affect the success of infrastructure management. This paper is primarily aimed to identify key stakeholders and responses that need to be applied to them. On the initial stage, a list of stakeholders was developed using research strategies such as case study and literature review. Sources were then chosen with certain criteria. They were assigned to score each stakeholder on the list. A stakeholder analysis was conducted to obtain a list of key stakeholders that have a significant impact on Jakarta's LRT.
\end{abstract}

Keywords: stakeholder analysis; light rail transit; infrastructure management

\begin{abstract}
Abstrak
[Judul: Pengaturan Stakeholder Light Rail Transit Jakarta Menggunakan Analisa Stakeholder] Keterlibatan stakeholder dalam pembangunan infrastruktur seperti pada Light Rail Transit (LRT) memiliki peran penting karena mempengaruhi tingkat keberhasilan manajemen infrastruktur. Artikel ini bertujuan untuk mengidentifikasi stakeholder utama berikut tindakan-tindakan yang perlu dilakukan terhadap stakeholder tersebut. Pada tahap awal, daftar stakeholder dibuat dengan menggunakan metode riset seperti studi kasus dan tinjauan literatur. Langkah ini diikuti dengan memilih sumberdaya dengan kriteria tertentu untuk memberikan penilaian atas setiap stakeholder yang telah terdaftar. Analisis stakeholder kemudian dilaksanakan untuk mendapatkan daftar stakeholder utama yang memiliki pengaruh signifikan terhadap LRT di Jakarta.
\end{abstract}

Kata kunci: analisis stakeholder; light rail transit, manajemen infrastruktur

\section{Introduction}

Framework scheme in transportation involves several interested parties. These parties, also called stakeholders, are the people, groups, or organizations that could impact or be impacted by a decision, activity, or the outcome of the project (Project Management Institute, 2013). The relations and interactions that emerge between these stakeholders will result in the management success level. This research limits the success level in terms of efficiency in cost, information and decision making. Jakarta's Light Rail Transit (LRT) is chosen as object research with consideration as follows: (1) the most sophisticated rail-based mass transportation in Jakarta so far (2) it will be used as official means of transportation in Asian Games 2018. In addition, the availability of rail-

\footnotetext{
*) Penulis Korespondensi.

E-mail: ayomi@eng.ui.ac.id

doi:10.14710/teknik.v38n2.16140
}

based mass transportation has significant impact in saturated areas with crowded population, congestion problems and space limitation (Susantono, 2013; Gray \& Hoel, 1992). This condition forced the regional government to proactively accelerate the constructionoperational phase of LRT which will involve new stakeholders.

LRT's Jakarta has initially planned with 7 corridors as seen in Figure 1. However, due to limitation of time and budget, the plan was revised into just 2 corridors. Total distance is $51.2 \mathrm{~km}$, covering (1) Kebayoran Lama-Kelapa Gading $(21.6 \mathrm{~km})$ and (2) Soekarno Hatta International Airport-Pantai Indah KapukPluit-Ancol-Kemayoran-Cempaka Putih $(30.5 \mathrm{~km})$. PT. Jakarta Propertindo, a regional state-owned company, is assigned to act on behalf of Provincial of DKI Jakarta. This leaves the company burden to solve the financial issues and the obligation to finish the construction on time. LRT is equipped with sophisticated technology but Copyright @ 2017, TEKNIK, p-ISSN 0852-1697, e-ISSN: 2460-9919 
the feature that makes LRT differs is the use of third rail system as electric source instead of overhead catenary system (OCS). The system has never been used before in Indonesia but in comparison one to another, it has more advantage than OCS (Table 1).

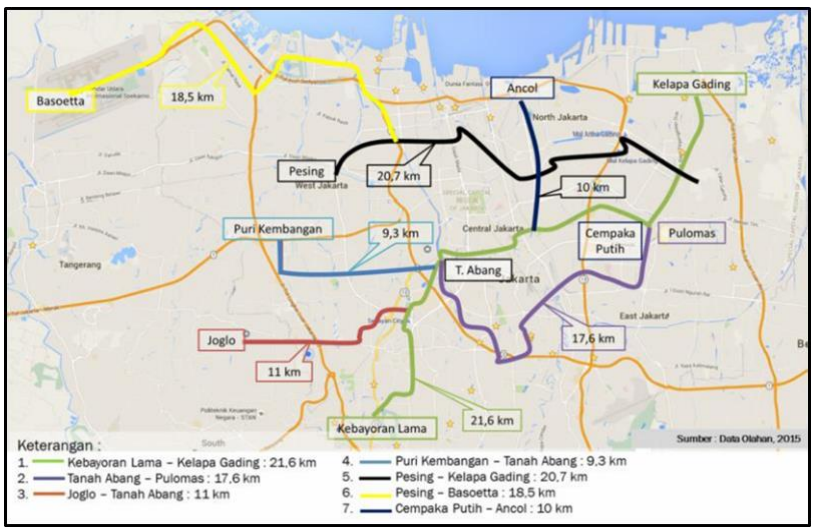

Figure 1. Jakarta's LRT Initial Route

Table 1. OCS and Third Rail System Comparison

\begin{tabular}{|c|c|c|}
\hline $\begin{array}{l}\text { Power } \\
\text { System }\end{array}$ & $\begin{array}{c}\text { Overhead } \\
\text { Catenary System } \\
\text { (OCS) }\end{array}$ & Third Rail System \\
\hline Reliability & $\begin{array}{c}\sqrt{ } \\
\text { (less reliable) }\end{array}$ & $\begin{array}{c}\sqrt{ } \sqrt{ } \\
\text { (more reliable) }\end{array}$ \\
\hline Maintenance & $\begin{array}{c}\sqrt{ } \\
\text { (more frequent ) } \\
\sqrt{ } \sqrt{ }\end{array}$ & $\begin{array}{c}\sqrt{ } \sqrt{ } \\
\text { (less frequent) } \\
\sqrt{ } \sqrt{ } \sqrt{ }\end{array}$ \\
\hline Efficiency & $\begin{array}{l}\text { (high } \\
\text { electromagnetic } \\
\text { interference) }\end{array}$ & $\begin{array}{c}\text { (no interference, better } \\
\text { distribution) }\end{array}$ \\
\hline Safety & $\begin{array}{c}\sqrt{ } \\
\text { (falling off OCS } \\
\text { column) }\end{array}$ & $\begin{array}{c}\sqrt{ } \sqrt{ } \\
\text { (anticipated with Railing } \\
\text { Platform and Emergency } \\
\text { Tripping Switch) }\end{array}$ \\
\hline Cost & $\begin{array}{c}\sqrt{ } \\
\text { (high cost) }\end{array}$ & $\begin{array}{c}\sqrt{ } \text { V } \\
\text { (low cost) }\end{array}$ \\
\hline Esthetic & $\sqrt{ }$ & $\sqrt{ } \sqrt{ }$ \\
\hline
\end{tabular}

\section{Research Methods}

Research starts with case study and literatures review, compiling theories, and seeking lesson learned from schemes that already established in other countries. Most of the reviewed case are success case but there is also the failed one. The purpose in using various cases is to determine the success or failure factors from each case. Research stages are described in Figure 2.

Data gathered in Stage-1 is used to compose the list of stakeholders (1st Secondary Data/ Ds-1). Next stage is to validate Ds-1 using sources, cq. 5 persons that met minimum criteria of 10 years work experience in the field of infrastructure. Ds-1 is a table consists of stakeholders and scores, range from 1 to 10 . The sources then validate the data by giving tickmark for each stakeholder based on the score. The result is validated list of stakeholders with scores (1st Primary Data/ Dp-1). Stakeholder analysis (SA) is used in Stage-2 to develop preliminary understanding of stakeholders interactions, roles, and responses (Schmeer, 1999). SA is "an approach for understanding a system and changes in it by identifying key actors or stakeholders and assessing their respective interest in that system" (Overseas Development Administration, 1995).

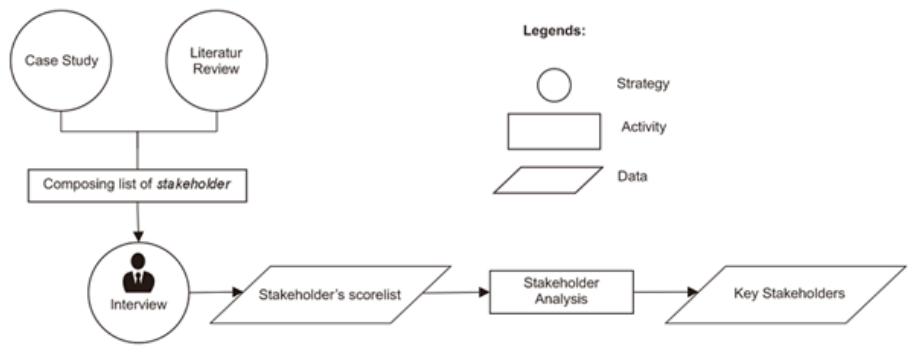

Figure 2. Research Sequential Stages

There are two types of matrix used in this research, (1) Matrix Influence-Interest to place the stakeholders by their roles and (2) Matrix Power-Interest to know the response from each stakeholder. The first matrix classified stakeholders according to their relative importance and interest in the project (Grimbl \& Wellard, 1997) which can then be used to determine how stakeholders might be engaged (Reed et al., 2009). The second matrix groupes the stakeholders based on their level of authority (power) and their level of concern (interest) regarding the project outcomes (Project Management Institute, 2013). Key stakeholders are stakeholders with key player roles and manage closely responses acquired from matrices in Figure 3.
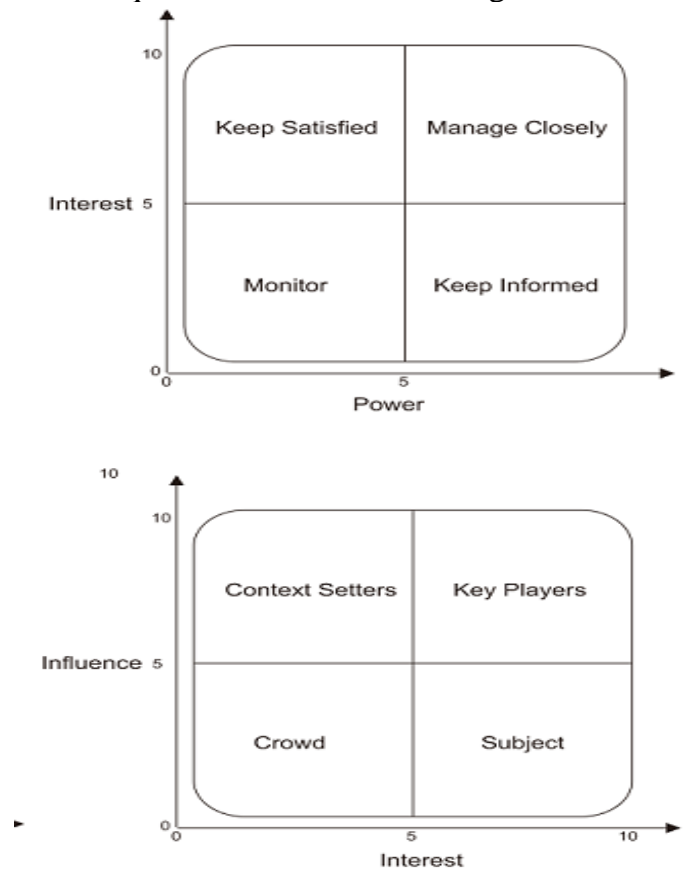

Figure 3. Stakeholder Analysis Matrices: Power-Interest (upper) and Influence-Interest (lower). 
Teknik, 37 (2), 2017, 73

\section{Results and discussion}

\subsection{Matrix Power-Interest}

Table 2 shows responses from each stakeholder. Code $\mathrm{N}$ represents a number of sources, code '-' means that there are two scores with the same quantity that caused mode cannot be concluded, N/A stands for "not available" which means the score placed right in the middle of matrix (score with value 5).

Table 2. Matrix Power-Interest

\begin{tabular}{|c|c|c|c|c|c|c|c|}
\hline No & Stakeholder & N1 & N2 & N3 & N4 & N5 & Mode \\
\hline 1 & $\begin{array}{l}\text { Provincial of DKI } \\
\text { Jakarta }\end{array}$ & $\mathrm{MC}$ & $\mathrm{MC}$ & $\mathrm{MC}$ & $\mathrm{MC}$ & $\mathrm{MC}$ & MC \\
\hline 2 & $\begin{array}{l}\text { Municipality of } \\
\text { Bogor }\end{array}$ & KS & M & M & N/A & $\mathrm{MC}$ & M \\
\hline 3 & $\begin{array}{l}\text { Municipality of } \\
\text { Depok }\end{array}$ & KS & M & M & N/A & $\mathrm{MC}$ & M \\
\hline 4 & $\begin{array}{l}\text { Municipality of } \\
\text { Tangerang }\end{array}$ & KS & M & M & N/A & $\mathrm{MC}$ & M \\
\hline 5 & $\begin{array}{l}\text { Municipality of } \\
\text { Bekasi }\end{array}$ & KS & M & M & N/A & $\mathrm{MC}$ & M \\
\hline 6 & $\begin{array}{l}\text { BUMD Jakarta } \\
\text { Propertindo }\end{array}$ & $\mathrm{MC}$ & N/A & $\mathrm{MC}$ & N/A & $\mathrm{MC}$ & MC \\
\hline 7 & $\begin{array}{l}\text { Central } \\
\text { Government cq. } \\
\text { Ministry of } \\
\text { Transportation }\end{array}$ & KS & MC & $\mathrm{MC}$ & $\mathrm{MC}$ & $\mathrm{MC}$ & MC \\
\hline 8 & Lenders & $\mathrm{MC}$ & M & $\mathrm{MC}$ & $\mathrm{MC}$ & $\mathrm{MC}$ & MC \\
\hline 9 & Operators & KS & N/A & $\mathrm{MC}$ & $\mathrm{MC}$ & MC & MC \\
\hline 10 & $\begin{array}{l}\text { House of } \\
\text { Representatives }\end{array}$ & KS & MC & $\mathrm{MC}$ & $\mathrm{MC}$ & $\mathrm{MC}$ & $\mathrm{MC}$ \\
\hline 11 & Investors & $\mathrm{KI}$ & M & $\mathrm{MC}$ & $\mathrm{MC}$ & MC & MC \\
\hline 12 & Sponsors & $\mathrm{KI}$ & M & $\mathrm{MC}$ & $\mathrm{MC}$ & $\mathrm{MC}$ & $\mathrm{MC}$ \\
\hline 13 & $\begin{array}{l}\text { PT. Penjaminan } \\
\text { Infrastruktur } \\
\text { Indonesia (Persero) }\end{array}$ & M & M & $\mathrm{MC}$ & N/A & $\mathrm{MC}$ & MC \\
\hline 14 & $\begin{array}{l}\text { Supervision } \\
\text { Consultant }\end{array}$ & $\mathrm{MC}$ & N/A & $\mathrm{MC}$ & N/A & $\mathrm{MC}$ & MC \\
\hline 15 & PT. Adhi Karya & $\mathrm{KS}$ & M & $\mathrm{KS}$ & N/A & $\mathrm{MC}$ & $\mathrm{KS}$ \\
\hline 16 & $\begin{array}{l}\text { PT. Kereta Api } \\
\text { Cepat Jakarta- } \\
\text { Bandung }\end{array}$ & M & M & M & N/A & $\mathrm{MC}$ & M \\
\hline 17 & $\begin{array}{l}\text { PT. KRL } \\
\text { Commuter } \\
\text { Jabodetabek }\end{array}$ & N/A & M & M & N/A & $\mathrm{MC}$ & M \\
\hline 18 & PT. MRT Jakarta & N/A & M & M & N/A & $\mathrm{MC}$ & M \\
\hline 19 & $\begin{array}{l}\text { PT. Transportasi } \\
\text { Jakarta }\end{array}$ & N/A & M & M & N/A & $\mathrm{MC}$ & M \\
\hline 20 & $\begin{array}{l}\text { Transportation City } \\
\text { Council of Jakarta }\end{array}$ & $\mathrm{MC}$ & N/A & N/A & N/A & $\mathrm{MC}$ & N/A \\
\hline 21 & $\begin{array}{l}\text { Metro Jaya Police } \\
\text { Department }\end{array}$ & N/A & N/A & M & $\mathrm{MC}$ & $\mathrm{MC}$ & - \\
\hline
\end{tabular}

The mode varies in five values with manage closely is the most likely response (10 out of 21). Regional governments adjacent with Jakarta have monitor response since their roles only as a supplier feeder for LRT's
Jakarta. PT. Adhi Karya has high interest but low power since they have a dominant part in the construction phase of LRT's Jabodebek but not in LRT's Jakarta. The plotted response on matrix can be seen in Figure 4.
N1

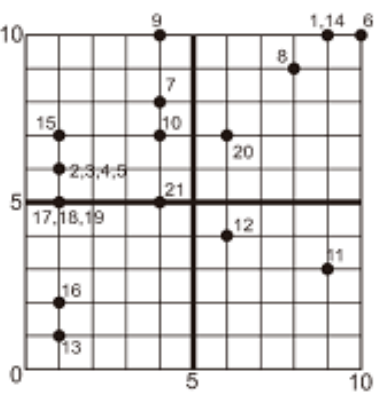

N3

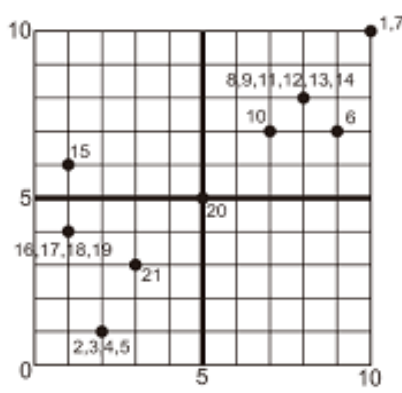

N2

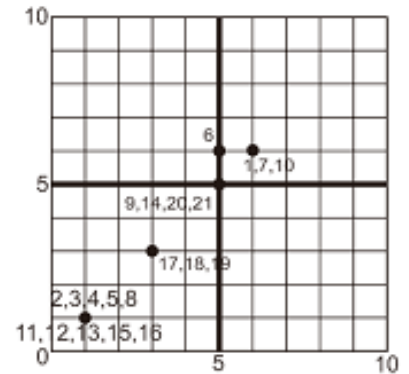

N4

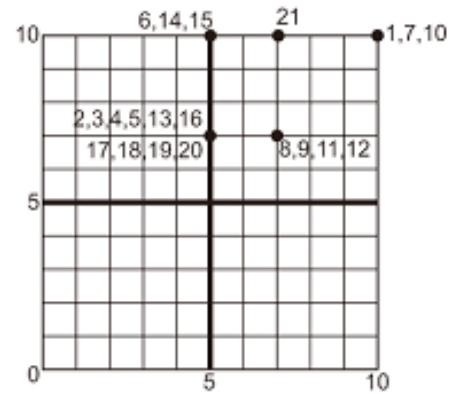

N5

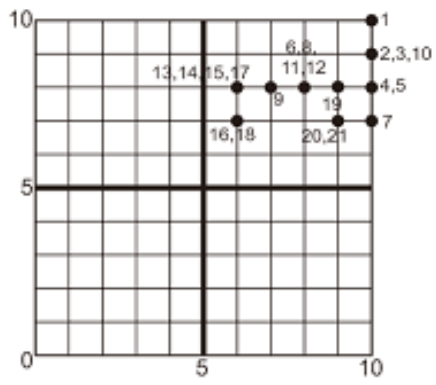

Figure 4. Power-Interest Matrix (Plotted)

3.2 Matrix Interest-Influence

Table 3 shows roles for each stakeholder. Code $\mathrm{N}$ represents a number of source, code '-' means that there are two scores with the same quantity that caused mode cannot be concluded, N/A stands for "not available" which means the score placed right in the middle of matrix (score with value 5).

There are 11 (out of 21) stakeholders classified as key players (KP) which means this group should be actively engaged as their involvement is essential. There is also crowd (C) group which have limited influence and little interest in the process and therefore there is little need to extensively engage with them. The plotted roles on the matrix can be seen in Figure 5. 
Teknik, 37 (2), 2017, 74

Table 3. Matrix Interest-Influence

\begin{tabular}{|c|c|c|c|c|c|c|}
\hline Stakeholder & N1 & $\mathbf{N 2}$ & N3 & N4 & N5 & Mode \\
\hline $\begin{array}{l}\text { Provincial of DKI } \\
\text { Jakarta }\end{array}$ & $\mathrm{KP}$ & $\mathrm{KP}$ & $\mathrm{KP}$ & $\mathrm{KP}$ & $\mathrm{KP}$ & $\mathrm{KP}$ \\
\hline Municipality of Bogor & S & $\mathrm{C}$ & $\mathrm{C}$ & $\mathrm{KP}$ & $\mathrm{KP}$ & $\mathrm{C}$ \\
\hline Municipality of Depok & $S$ & $\mathrm{C}$ & $\mathrm{C}$ & $\mathrm{KP}$ & $\mathrm{KP}$ & $\mathrm{C}$ \\
\hline $\begin{array}{l}\text { Municipality of } \\
\text { Tangerang }\end{array}$ & $S$ & $\mathrm{C}$ & $\mathrm{C}$ & $\mathrm{KP}$ & $\mathrm{KP}$ & $\mathrm{C}$ \\
\hline Municipality of Bekasi & S & $\mathrm{C}$ & $\mathrm{C}$ & $\mathrm{KP}$ & $\mathrm{KP}$ & $\mathrm{C}$ \\
\hline $\begin{array}{l}\text { BUMD Jakarta } \\
\text { Propertindo }\end{array}$ & $\mathrm{KP}$ & N/A & $\mathrm{KP}$ & $\mathrm{KP}$ & $\mathrm{KP}$ & KP \\
\hline $\begin{array}{l}\text { Central Government cq. } \\
\text { Ministry of } \\
\text { Transportation }\end{array}$ & $S$ & $\mathrm{KP}$ & $\mathrm{KP}$ & $\mathrm{KP}$ & $\mathrm{KP}$ & KP \\
\hline Lenders & KP & $\mathrm{C}$ & $\mathrm{KP}$ & $\mathrm{KP}$ & $\mathrm{KP}$ & $\mathrm{KP}$ \\
\hline Operators & S & N/A & $\mathrm{KP}$ & $\mathrm{KP}$ & $\mathrm{KP}$ & $\mathrm{KP}$ \\
\hline $\begin{array}{l}\text { House of } \\
\text { Representatives }\end{array}$ & $S$ & $\mathrm{KP}$ & $\mathrm{KP}$ & $\mathrm{KP}$ & $\mathrm{KP}$ & KP \\
\hline Investors & $\mathrm{CS}$ & $\mathrm{C}$ & $\mathrm{KP}$ & $\mathrm{KP}$ & $\mathrm{KP}$ & $\mathrm{KP}$ \\
\hline Sponsors & $\mathrm{CS}$ & $\mathrm{C}$ & $\mathrm{KP}$ & $\mathrm{KP}$ & $\mathrm{KP}$ & KP \\
\hline $\begin{array}{l}\text { PT. Penjaminan } \\
\text { Infrastruktur Indonesia } \\
\text { (Persero) }\end{array}$ & $\mathrm{C}$ & $\mathrm{C}$ & $\mathrm{KP}$ & $\mathrm{KP}$ & $\mathrm{KP}$ & KP \\
\hline Supervision Consultant & KP & N/A & $\mathrm{KP}$ & $\mathrm{KP}$ & $\mathrm{KP}$ & KP \\
\hline PT. Adhi Karya & $S$ & $\mathrm{C}$ & $\mathrm{S}$ & $\mathrm{KP}$ & $\mathrm{KP}$ & - \\
\hline $\begin{array}{l}\text { PT. Kereta Api Cepat } \\
\text { Jakarta-Bandung }\end{array}$ & $\mathrm{C}$ & $\mathrm{C}$ & $\mathrm{C}$ & $\mathrm{KP}$ & $\mathrm{KP}$ & $\mathrm{C}$ \\
\hline $\begin{array}{l}\text { PT. KRL Commuter } \\
\text { Jabodetabek }\end{array}$ & N/A & $\mathrm{C}$ & $\mathrm{C}$ & $\mathrm{KP}$ & $\mathrm{KP}$ & - \\
\hline PT. MRT Jakarta & N/A & $\mathrm{C}$ & $\mathrm{C}$ & $\mathrm{KP}$ & $\mathrm{KP}$ & - \\
\hline PT. Transportasi Jakarta & N/A & $\mathrm{C}$ & $\mathrm{C}$ & $\mathrm{KP}$ & $\mathrm{KP}$ & - \\
\hline $\begin{array}{l}\text { Transportation City } \\
\text { Council of Jakarta }\end{array}$ & $\mathrm{KP}$ & N/A & N/A & $\mathrm{KP}$ & $\mathrm{KP}$ & KP \\
\hline $\begin{array}{l}\text { Metro Jaya Police } \\
\text { Department }\end{array}$ & N/A & N/A & $\mathrm{C}$ & $\mathrm{KP}$ & $\mathrm{KP}$ & - \\
\hline
\end{tabular}

Dots in Figure 4 and 5 are distributed in the same manner for each source. N1, N3 have spread distribution across the matrix while $\mathrm{N} 2, \mathrm{~N} 4$ and N5 concentrate in a particular quadrant. This manner is a result of sources perception of power and influence which they considered as similar. By definition, power measures the resources that a stakeholder can mobilize to express their support or opposition (Archi et al., 2010) while influence is the power that stakeholders have over the project-to control what decisions are made, facilitate its implementation or exert influence that affects the project negatively (Merama \& Chatupote, 2013). Both are equally important in analysis and in achieving the goals.
N1

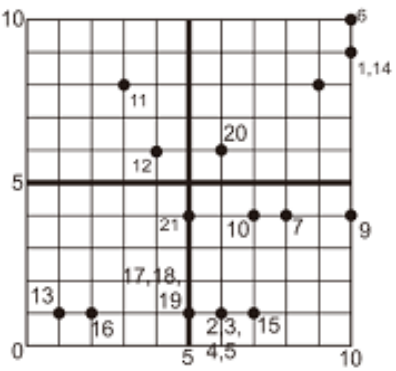

N3
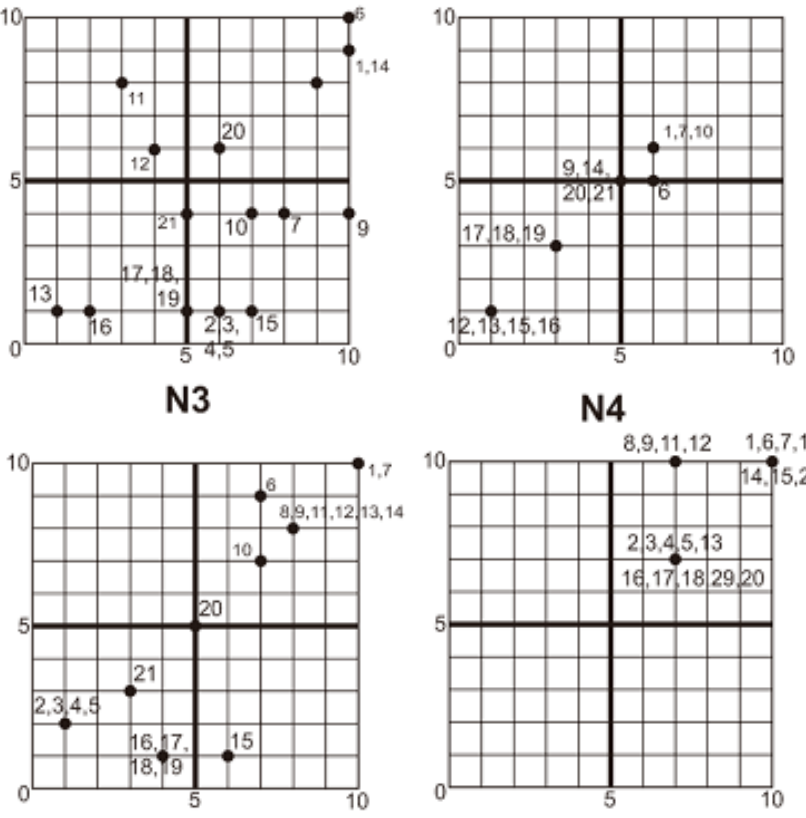

N4

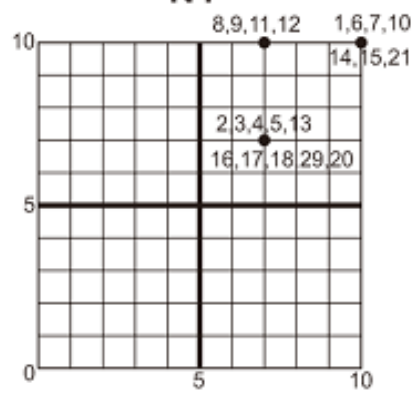

N5

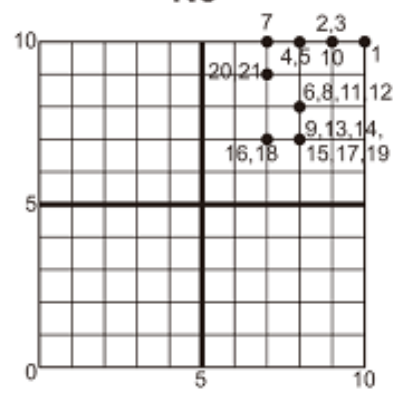

Figure 5. Interest-Influence Matrix (Plotted)

By confronting Table 2 and 3, we will have list of key stakeholders which are stakeholders with key player roles and manage closely responses as shown in Table 4.

Table 4. List of Key Stakeholders

\section{Key Stakeholder}

\begin{tabular}{ll}
\hline a & Provincial of DKI Jakarta \\
b & BUMD Jakarta Propertindo \\
& Central Government cq. Ministry of Transportation cq. \\
c & Directorate General of Railways \\
d & Lenders \\
e & Operator \\
f & DKI Jakarta House of Representatives \\
g & Investors \\
h & Sponsors \\
i & PT. Penjaminan Infrastruktur Indonesia (Persero) \\
j & Supervision Consultant \\
\hline
\end{tabular}


Teknik, 37 (2), 2017, 75

These 'key stakeholders' hold significant impact on the project therefore crucial action must be taken to maintain their involvement during project cycle.

\section{Conclusion}

Jakarta's LRT existing condition might change in the coming years, new stakeholders involvement in the management will affect many things such as policy making, corporate action, and service delivered. In order to cover these changes, a stakeholder analysis is needed to be taken since the right treatment of key stakeholders will result in management efficiency. Power-interest and interest-influence matrix has been used in this research to find key stakeholders. The analysis is done by scoring each stakeholder based on power and influence interest by sources. The scores are then used in the matrix to find degree of involvement. Key stakeholders are stakeholders with managing closely response and key player role. They have significant impact on the process and need to manage extensively until the project ended.

\section{References}

Archi, R., Ruchi, B., Syed, A.H., Gordon, M. H. (2010). Assessing The Utility of Stakeholder Analysis to Protected Areas Management: The Case of Corbett National Park, India. Biological Conservation, 143, 2956-2964.
Gray, G. E., Hoel, L. E. (1992). Public Transportation 2nd Edition. New Jersey: Prentice-Hall, Inc.

Grimble, R., Wellard, K. (1997) Stakeholder Methodologies in Natural Resource Management: A Review of Principles, Contexts, Experiences and Opportunities. Agricultural System, 55(2), 173-93.

Meraman, M., Chatupote, W. (2013). Stakeholder Analysis to Sustainable Land Management of Pak Phanang River Basin, Thailand, Procedia-Social and Behavioral Sciences, 91, 349-356.

Overseas Development Administration (1995). Guidance Note on How To Do Stakeholder Analysis of Aid Projects and Programmes. London: ODA.

Project Management Institute (2013). A Guide To The Project Management Body of Knowledge. Pennsylvania: Project Management Institute.

Reed, M.S., Graves, A., Dandy, N., Posthumus, H., Hubacek, K., Morris J. (2009) Who's in and Why? A Typology of Stakeholder Analysis Methods for Natural Resource Management. Journal of Environmental Management, 90, 1933-49.

Schmeer, K. (1999). Guidelines for Conducting a Stakeholder Analysis. MD, Partnership for Health Reform, Abt Associates Inc., Bethesda.

Susantono, B. (2013). Transportasi \& Investasi: Tantangan dan Perspektif Multidimensi. Jakarta: Kompas. 